\title{
Pengaruh motivasi belajar dan perhatian orang tua terhadap prestasi belajar matematika siswa kelas VIII SMPK
}

\section{Gusti Ayu Rarasanti ${ }^{*}$, Ketut Sarjana ${ }^{2}$, Sudi Prayitno², Sripatmi ${ }^{2}$}

\author{
${ }^{1}$ Mahasiswa Pendidikan Matematika, FKIP, Universitas Mataram, Mataram \\ 2 Pendidikan Matematika, FKIP, Universitas Mataram, Mataram
}

rarasanti1997@gmail.com

Diterima: 16-09-2021; Direvisi: 26-09-2021; Dipublikasi: 30-09-2021

\begin{abstract}
This study aims to determine the effect of learning motivation and parental attention on mathematics learning achievement of grade VIII students at SMPK Tunas Daud Mataram 2020/2021. This type of research is ex-post facto. The sample class was selected using a saturated sampling technique, obtained 34 students consisting of 2 classes. Data retrieval in this study was carried out by providing a questionnaire on learning motivation and parental attention and a number pattern test. Analysis of SPSS 21 program data, consisting of prerequisite tests and hypothesis testing. The prerequisite test on the data analysis used, namely the normality test of the results obtained on learning motivation, namely 0.245 and parental attention, namely 0.162 so that it is said that the data is normally distributed, the linearity test of the results obtained on learning motivation is 0.958 and parents' attention is 0.597 so that The data has a relationship with learning achievement and the multicollinearity test of the results obtained is 1.340 , namely there is no relationship between independent variables. The contribution of learning motivation to mathematics learning achievement was $19.6 \%$ and parents' attention to mathematics learning achievement was $19.2 \%$. The existence of a positive relationship between learning motivation and learning achievement and parents' attention to learning achievement is indicated by a positive correlation coefficient. A positive coefficient value indicates that the higher the motivation to learn and the attention of parents, the higher the student's learning achievement.
\end{abstract}

Keywords: learning motivation; mathematics learning achievement; parents' attention

\begin{abstract}
Abstrak
Penelitian ini bertujuan untuk mengetahui pengaruh motivasi belajar dan perhatian orang tua terhadap prestasi belajar matematika siswa kelas VIII di SMPK Tunas Daud Mataram tahun pelajaran 2020/2021. Jenis penelitian ini ex-post facto. Kelas sampel dipilih menggunakan Sampling Jenuh, diperoleh 34 siswa yang terdiri dari 2 kelas. Pengambilan data dalam penelitian ini dilakukan dengan memberikan kuesioner motivasi belajar dan perhatian orang tua dan tes pola bilangan. Analisis data program SPSS 21, terdiri dari uji prasyarat dan uji hipotesis. Uji prasyarat pada analisis data yang digunakan, yaitu uji normalitas hasil didapatkan pada motivasi belajar yaitu 0,245 dan perhatian orang tua yaitu 0,162 sehingga dikatakan data berdistribusi normal, uji linieritas hasil yang didapat pada motivasi belajar yaitu 0,958 dan perhatian orang tua yaitu 0,597 sehingga data memiliki hubungan terhadap prestasi belajar dan uji multikolinieritas hasil yang diperoleh yaitu 1,340 yaitu tidak terdapat hubungan antar variabel bebas. Besar sumbangan motivasi belajar terhadap prestasi belajar matematika sebesar 19,6\% dan perhatian orang tua terhadap prestasi belajar matematika sebesar 19,2\%. Adanya hubungan yang positif antara motivasi belajar terhadap prestasi belajar dan perhatian orang tua terhadap prestasi belajar ditunjukkan dengan nilai koefisien korelasi yang positif. Nilai koefisien yang positif menunjukkan bahwa semakin tinggi motivasi belajar dan perhatian orang tua maka semakin pula prestasi belajar siswa.
\end{abstract}

Kata Kunci: motivasi belajar; perhatian orang tua; prestasi belajar matematika 


\section{PENDAHULUAN}

Pendidikan merupakan kebutuhan yang sangat penting dalam kehidupan. Kebutuhan terhadap pendidikan dapat dirasakan dalam segala segi kehidupan manusia. Hampir tidak bisa disangkal bahwa apa yang diperoleh sekarang adalah buah dari proses pembangunan pendidikan yang mengarah kepada kemajuan suatu bangsa. Proses belajar mengajar merupakan faktor utama yang mempengaruhi kualitas hasil belajar siswa dan kualitas pendidikan yang dimotori oleh guru (Maonde, 2011). Pada hasil ratarata nilai dan ketuntasan dari prestasi belajar siswa tergolong sedang. Namun pada kenyataannya siswa sudah mulai bosan belajar dari rumah yang mengakibatkan siswa terlambat mengerjakan tugas dan nilai hariannya menurun.

Berdasarkan hasil observasi dan wawancara terlihat bahwa ketika guru menjelaskan materi pelajaran melalui daring ada beberapa siswa cenderung melamun tidak memperhatikan gurunya menjelaskan. Selain itu, saat guru memberi pertanyaan hanya beberapa siswa yang mampu menjawab pertanyaan guru dan bertanya mengenai materi pelajaran yang belum dikuasai, dan saat guru memberikan tugas ada beberapa siswa yang tidak mengerjakan atau mengumpulkan tugas tidak tepat waktu. Sejalan dengan pendapat Sobur (2003) mengatakan bahwa motivasi merupakan penggerak dari dalam diri untuk berbuat sesuatu dalam rangka mencapai suatu kepuasan atau tujuan tertentu. Dari perilaku yang tampak sesungguhnya merupakan indikator dari motivasi.

Dari hasil wawancara dengan guru mata pelajaran diketahui bahwa dua dari keseluruhan jumlah siswa di kelas tidak memiliki orang tua dan mengharuskannya tinggal di panti asuhan. Kurangnya sarana penunjang dalam belajar daring / online seperti handphone, membuat prestasi belajarnya rendah. Sejalan dengan fakta diatas menurut Slameto (2010) orang tua yang kurang atau tidak memperhatikan pendidikan anaknya, misalnya mereka yang tak peduli terhadap pemenuhan kepentingan dan kebutuhan dalam belajar, tidak melakukan pemantauan waktu belajar anaknya akan menyebabkan kurang berhasil dalam belajar. Menurut Suryabrata (2011) ada beberapa hal yang mendorong siswa memiliki motivasi belajar, yaitu: 1. Adanya sifat ingin tahu; 2. Adanya sifat ingin terus maju; 3. Adanya keinginan untuk mendapatkan perhatian orang tua dan guru; 4. Adanya keinginan memperbaiki kegagalan; 5. Adanya hukuman pada akhir pembelajaran.

Sebagian orang tua siswa ada yang sibuk dengan pekerjaan mereka membuat siswa kurang mendapat perhatian dari orang tuanya. Ada juga kasus siswa yang terbiasa di rumahnya menggunakan bahasa asing membuat siswa kurang paham dengan bahasa Indonesia dan tugas-tugas yang diberikan guru. Maka siswa tersebut perlu bimbingan dari orang tuanya dalam mengerjakan soal-soal yang diberikan guru. Menurut Sadirman (2014) mengatakan orang tua selaku pendidik pertama dalam keluarga berperan dalam pemberian perhatian yang dapat membantu anak dalam proses belajar di sekolah. Adapula anak-anak yang tinggal di panti asuhan yang kurang mendapat perhatian ibu pengasuh yang menggantikan orang tua kandung mereka. Dan pengasuh 
di panti juga harus membagi waktu mereka untuk keluarga dan anak-anak di panti sehingga perhatian mereka menjadi kurang. Menurut Ahmadi (2009) ada beberapa faktor yang mempengaruhi perhatian orang tua diantaranya adalah 1 . Pembawaan; 2. Kebiasaan; 3. Kebutuhan; 4. Kewajiban; 5. Keadaan jasmani; 6. Suasana jiwa. Apa yang terjadi seperti diungkap di atas merupakan indikator perhatian orang tua dalam proses pencapaian hasil belajar oleh siswa

\section{METODE PENELITIAN}

Metode penelitian yang digunakan adalah metode ex-post facto yaitu mengkaji keterkaitan variabel bebas dan variabel terikat. Variabel yang diteliti yaitu Motivasi belajar $\left(X_{1}\right)$, perhatian orang tua $\left(X_{2}\right)$ dan prestasi belajar matematika (Y). Populasi dan sampel penelitian ini adalah 34 siswa yang tersebar di 2 kelas SMPK Tunas Daud Mataram. Instrumen penelitian yang digunakan adalah kuesioner (angket) dan tes.

Uji validitas isi dari 2 validator ahli yang menyebut bahwa instrumen telah valid. Teknik analisis data yang digunakan dalam penelitian ini adalah regresi linier berganda dengan rumus sebagai berikut: $Y=a+b_{1} X_{1}+b_{2} X_{2} \quad$ (Sugiyono, 2016)

$a=\frac{\sum y}{n}-b_{1}\left(\frac{\sum X_{1}}{n}\right)-b_{2}\left(\frac{\sum X_{2}}{n}\right)$

$b_{1}=\frac{\left(\sum X_{2}^{2}\right)\left(\sum X_{1} Y\right)-\left(\sum X_{1} X_{2}\right)\left(\sum X_{2} Y\right)}{\left(\sum X_{1}^{2}\right)\left(\sum X_{2}^{2}\right)-\left(\sum X_{1} X_{2}\right)^{2}}$

$b_{2}=\frac{\left(\sum X_{1}^{2}\right)\left(\sum X_{2} Y\right)-\left(\sum X_{1} X_{2}\right)\left(\sum X_{1} Y\right)}{\left(\sum X_{1}^{2}\right)\left(\sum X_{2}^{2}\right)-\left(\sum X_{1} X_{2}\right)^{2}}$

Keterangan:

$Y=$ Variabel terikat

$X_{1}=$ Variabel motivasi belajar

$X_{2}=$ Variabel perhatian orang tua

Untuk dapat menggunakan analisis regresi linier, uji prasyarat telah dipenuhi karena data berdistribusi normal, hal ini ditunjukkan oleh nilai signifikansi (Asymp Sig. (2tailed)) motivasi belajar sebesar 0,245 dan perhatian orang tua sebesar 0,162 kedua nilai signifikansi tersebut $>0,05$ maka sebaran data yang diperoleh berdistribusi normal. Data linier, hal ini ditunjukkan oleh nilai signifikansi (Deviation From Linearity) motivasi belajar sebesar 0,958 > 0,05 dan perhatian orang tua sebesar 0,597 $>0,05$ sehingga terdapat hubungan antara motivasi belajar terhadap prestasi belajar dan perhatian orang tua terhadap prestasi belajar matematika. Pada data tidak ada gejala multikolinieritas, hal ini ditunjukkan oleh nilai VIF motivasi belajar dan perhatian orang tua sebesar $1,340 \leq 10$ dimana tidak terdapat hubungan yang linier antar variabel bebas yaitu motivasi belajar dan perhatian orang tua. 


\section{HASIL PENELITIAN}

Pengujian hipotesis dan analisis data dilakukan dengan bantuan software SPSS 21. Hasil pengujian hipotesis dapat dilihat pada tabel berikut:

Hasil analisis mengenai regresi linier dan uji t pada motivasi belajar terhadap prestasi belajar menunjukkan hasil seperti pada Tabel 1.

Tabel 1. Hasil Analisis Regresi Linier dan Uji t Motivasi Belajar terhadap Prestasi Belajar

\begin{tabular}{|c|c|c|c|c|c|}
\hline \multirow[b]{3}{*}{ Model } & \multicolumn{3}{|c|}{ Coefficients $^{a}$} & \multirow[b]{3}{*}{$\mathrm{t}$} & \multirow[b]{3}{*}{ Sig. } \\
\hline & \multicolumn{2}{|c|}{$\begin{array}{c}\text { Unstandardized } \\
\text { Coefficients }\end{array}$} & $\begin{array}{c}\text { Standardiz } \\
\text { ed } \\
\text { Coefficient } \\
\text { s }\end{array}$ & & \\
\hline & $\mathrm{B}$ & Std. Error & Beta & & \\
\hline $\begin{array}{l}\text { ] (Constan } \\
\text { t) }\end{array}$ & 41,671 & 11,098 & & 3,755 & ,001 \\
\hline $\begin{array}{l}\text { MOTIVA } \\
\text { SI }\end{array}$ & ,428 &, 153 & ,443 & 2,797 & ,009 \\
\hline
\end{tabular}

Hasil analisis mengenai korelasi parsial pada motivasi belajar terhadap prestasi belajar menunjukkan hasil seperti pada Tabel 2 .

Tabel 2. Hasil Analisis Korelasi Parsial Motivasi Belajar terhadap Prestasi Belajar

\begin{tabular}{|l|l|l|l|l|}
\hline & & & Model Summary \\
Model & $\mathrm{R}$ & R Square & $\begin{array}{l}\text { Adjusted } \\
\text { Square }\end{array}$ & $\begin{array}{l}\text { Rtd. Error } \\
\text { of the } \\
\text { Estimate }\end{array}$ \\
\hline 1 &, $443^{\mathrm{a}}$ &, 196 &, 171 & 8,54587 \\
\hline
\end{tabular}

Hasil analisis mengenai regresi linier dan uji $\mathrm{t}$ pada perhatian orang tua terhadap prestasi belajar menunjukkan hasil seperti pada Tabel 3. 
Tabel 3. Hasil Analisis Regresi dan Uji t Perhatian Orang Tua terhadap Prestasi Belajar

\section{Coefficients $^{a}$}

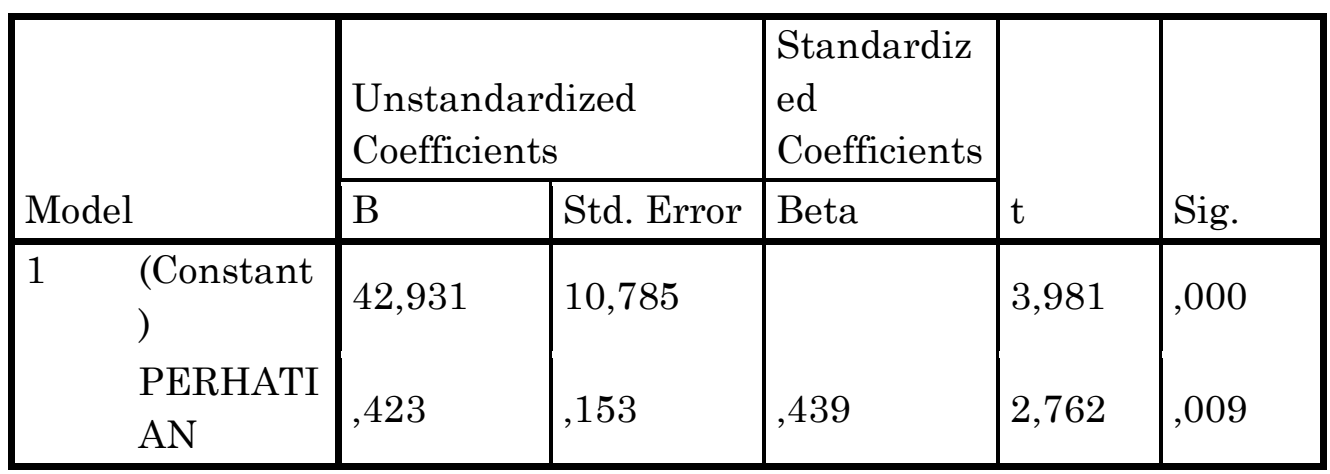

Hasil analisis mengenai korelasi parsial pada perhatian orang tua terhadap prestasi belajar menunjukkan hasil seperti pada Tabel 4.

Tabel 4. Hasil Analisis Korelasi Parsial Perhatian Orang Tua terhadap Prestasi Belajar

\section{Model Summary}

\begin{tabular}{|l|r|r|c|r|}
\hline Model & R & R Square & $\begin{array}{c}\text { Adjusted R } \\
\text { Square }\end{array}$ & $\begin{array}{c}\text { Std. Error of } \\
\text { the Estimate }\end{array}$ \\
\hline 1 &, $439^{\mathrm{a}}$ &, 192 &, 167 & 8,56689 \\
\hline
\end{tabular}

a. Predictors: (Constant), PERHATIAN

Hasil analisis mengenai regresi berganda pada motivasi belajar dan perhatian orang tua terhadap prestasi belajar menunjukkan hasil seperti pada Tabel 5.

Tabel 5. Hasil Analisis Regresi Berganda Motivasi Belajar dan Perhatian Orang Tua terhadap Prestasi Belajar

\section{Coefficients $^{\mathrm{a}}$}

\begin{tabular}{|c|c|c|c|c|c|c|}
\hline \multirow[b]{2}{*}{ Mod } & & \multicolumn{2}{|c|}{$\begin{array}{c}\text { Unstandardized } \\
\text { Coefficients }\end{array}$} & \multirow{2}{*}{$\begin{array}{c}\text { Standard } \\
\text { ized } \\
\text { Coefficie } \\
\text { nts } \\
\text { Beta }\end{array}$} & \multirow[b]{2}{*}{$\mathrm{t}$} & \multirow[b]{2}{*}{ Sig. } \\
\hline & & B & $\begin{array}{l}\text { Std. } \\
\text { Error }\end{array}$ & & & \\
\hline \multirow[t]{3}{*}{1} & $\begin{array}{l}\text { (Constan } \\
\text { t) }\end{array}$ & 6,736 & ,340 & & 19,794 & ,000 \\
\hline & $\begin{array}{l}\text { MOTIVA } \\
\text { SI }\end{array}$ & ,335 & ,083 & ,335 & 4,019 & ,000 \\
\hline & $\begin{array}{l}\text { PERHA } \\
\text { TIAN }\end{array}$ & ,669 & ,084 & ,665 & 7,986 & ,000 \\
\hline
\end{tabular}


Hasil analisis mengenai korelasi berganda pada motivasi belajar dan perhatian orang tua terhadap prestasi belajar menunjukkan hasil seperti pada Tabel 6 .

Tabel 6 Hasil Analisis Korelasi Berganda Motivasi Belajar dan Perhatian Orang Tua terhadap Prestasi Belajar

Model Summary

\begin{tabular}{|l|r|r|r|r|}
\hline Model & R & R Square & $\begin{array}{c}\text { Adjusted R } \\
\text { Square }\end{array}$ & $\begin{array}{c}\text { Std. Error of } \\
\text { the Estimate }\end{array}$ \\
\hline 1 &, $889^{\mathrm{a}}$ &, 791 &, 777 & 6,371 \\
\hline
\end{tabular}

a.Predictors: (Constant), Perhatian, Motivasi

Hasil analisis mengenai uji $\mathrm{F}$ pada motivasi belajar dan perhatian orang tua terhadap prestasi belajar menunjukkan hasil seperti pada Tabel 7.

Tabel 7. Hasil Analisis Uji F Motivasi Belajar dan Perhatian Orang Tua terhadap Prestasi Belajar

\section{ANOVA $^{a}$}

\begin{tabular}{|c|r|c|c|c|l|}
\hline Model & $\begin{array}{r}\text { Sum of } \\
\text { Squares }\end{array}$ & df & $\begin{array}{c}\text { Mean } \\
\text { Square }\end{array}$ & F & Sig. \\
\hline Regression & 4754,95 & 2 & 2377,47 & 58,582 &, $000^{\mathrm{b}}$ \\
6 & & 8 & & \\
& 1258,10 & 31 & 40,584 & & \\
3 & & & & \\
Residual & 6013,05 & 33 & & & \\
& 9 & & & & \\
\hline
\end{tabular}

a. Dependent Variable: Prestasi

b. Predictors: (Constant), Perhatian, Motivasi

\section{PEMBAHASAN}

Bagian ini memaparkan simpulan penelitian sesuai dengan hasil dan temuan penelitian. Bagian ini tidak perlu ada kutipan atas simpulan. Kesimpulan menggambarkan jawaban atas hipotesis dan / atau tujuan penelitian atau temuan ilmiah yang diperoleh. Kesimpulan tidak mengandung pengulangan hasil dan diskusi, melainkan merangkum temuan seperti yang diharapkan dalam tujuan atau hipotesis.

Penelitian ini bertujuan untuk mengetahui apakah terdapat pengaruh yang signifikan dari motivasi belajar dan perhatian orang tua terhadap prestasi belajar matematika siswa kelas VIII di SMPK Tunas Daud Mataram Tahun Pelajaran 2020/2021 dengan responden sebanyak 34 siswa. Dalam penelitian ini, peneliti menggunakan instrumen berupa kuesioner dan tes yang diambil secara daring. Peneliti telah menguji validitas instrumen kuesioner kepada validator ahli sebelum dilakukan penelitian. Kemudian 
dilakukan perbaikan pada instrumen kuesioner dan tes sesuai dengan saran validator ahli.

Setelah data terkumpul peneliti melakukan analisis statistik inferensial, analisis ini digunakan untuk mengetahui apakah terdapat pengaruh antara variabel bebas dengan variabel terikat dengan menggunakan uji korelasi dan uji regresi. Sebelumnya peneliti, terlebih dahulu melakukan uji asumsi yaitu berupa normalitas, linieritas dan multikolinieritas. Hasil uji asumsi menunjukkan semua variabel telah memenuhi syarat sehingga dapat dilanjutkan ke uji korelasi dan regresi. Dari hasil analisis korelasi parsial diketahui terdapat hubungan yang positif antara motivasi belajar terhadap prestasi belajar siswa. Hal ini ditunjukkan dengan nilai koefisien korelasi yang positif sebesar 0,443. Nilai koefisien korelasi yang positif menunjukkan bahwa semakin tinggi motivasi belajar maka semakin tinggi pula prestasi belajar siswa. Berdasarkan nilai uji $\mathrm{t}$ diperoleh $0,009<0,05$ sehingga dapat disimpulkan bahwa terdapat pengaruh motivasi belajar terhadap prestasi belajar matematika siswa kelas VIII di SMPK Tunas Daud Mataram Tahun Pelajaran 2020/2021. Persamaan regresinya yaitu $\hat{Y}=41,671+0,428 X$ dengan besar sumbangan motivasi belajar terhadap prestasi belajar matematika siswa kelas VIII di SMPK Tunas Daud Mataram Tahun Pelajaran 2020/2021 sebesar 19,6 \%. Hal ini sejalan dengan penelitian Gusnawati, Bey, dan Hasnawati (2019) yang menyatakan motivasi belajar memberikan pengaruh terhadap hasil belajar matematika siswa kelas VIII SMPN 1 Sawerigadi, yang ditunjukkan dengan $\hat{Y}=39,497+0,439 x$ dengan besarnya kontribusi yaitu $35 \%$. Hal ini juga didukung oleh pernyataan Maunah (2013) bahwa motivasi adalah pengembangan aktifitas dan inisiatif yang mampu mengarahkan ketekunan dalam melakukan kegiatan belajar. Siswa yang tampaknya tidak termotivasi, mungkin pada kenyataannya cukup berprestasi tetapi tidak sesuai dengan harapan pengajar. Sebagai contoh ada siswa yang cukup berprestasi di sekolah tetapi teman-temannya mempengaruhinya sehingga siswa tidak lagi berprestasi. Selain itu Sripatmi (2019) menyatakan bahwa faktor yang datang dalam diri siswa adalah motivasi dan kebiasaan belajar. Selain tidak adanya motivasi, ketidak-tertarikan siswa terhadap suatu pelajaran menjadi penyebab utama siswa tidak memperhatikan guru dan mencatat penjelasan dari guru. Adapun faktor lain yang mempengaruhi motivasi belajar salah satunya motivasi ekstrinsik. Menurut Sadirman (dalam Susanti, 2015) mengatakan motivasi belajar adalah rangsangan dari luar diri individu. Motivasi ekstrinsik juga penting sebab keadaan siswa dapat berubah-ubah dan kemungkinan lain proses belajar mengajar yang kurang menarik bagi siswa.

Pada hasil analisis korelasi parsial antara perhatian orang tua terhadap prestasi belajar siswa menunjukkan hubungan yang positif. Hal ini ditunjukkan dengan nilai koefisien korelasi yang positif sebesar 0,439. Nilai ini menunjukkan bahwa semakin tinggi perhatian orang tua maka semakin tinggi pula prestasi belajar siswa. Berdasarkan nilai uji $\mathrm{t}$ diperoleh $0,009<0,05$ sehingga dapat disimpulkan bahwa terdapat pengaruh perhatian orang tua terhadap prestasi belajar matematika siswa kelas VIII di SMPK Tunas Daud Mataram Tahun Pelajaran 2020/2021. Persamaan 
regresinya yaitu $\hat{Y}=42,931+0,423 X$ dengan besar pengaruh orang tua terhadap prestasi belajar matematika siswa kelas VIII di SMPK Tunas Daud Mataram Tahun Pelajaran 2020/2021 sebesar 19,2 \%. Hal ini sejalan dengan penelitian Sari dan Harini (2016) yang menyatakan adanya pengaruh yang kuat antara perhatian orang tua dengan prestasi belajar dengan besar kontribusi yaitu 28,74 \%. Hal ini juga didukung oleh pernyataan Slameto (2010) yang menyatakan bahwa perhatian orang tua berupa cara mendidik anak-anaknya akan sangat berpengaruh pada kegiatan belajarnya. Siswa yang kurang memperoleh perhatian orang tua dapat menyebabkan anak kurang berhasil dalam proses belajarnya. Malone (dalam Handayani, 2013) menerangkan bahwa keterlibat orang tua berpengaruh positif pada prestasi belajar akademik siswa. Peran orang tua yang kaitannya dengan prestasi belajar dapat dilakukan melalui memberikan bimbingan, penghargaan, meluangkan waktu berbincang-bincang dengan siswa dan mengontrol belajar siswa. Dengan adanya peran tersebut akan menumbuhkan semangat siswa dan perolehan prestasi belajarnya menjadi optimal. Namun yang terjadi di lapangan adalah beberapa orang tua sibuk menjalankan bisnisnya sehingga mengabaikan siswa dalam hal perkembangan belajarnya di sekolah dan selama pelajaran berlangsung siswa terlihat tidak bersemangat.

Selanjutnya, pengaruh hubungan antara motivasi belajar $\left(\mathrm{X}_{1}\right)$ dan perhatian orang tua $\left(\mathrm{X}_{2}\right)$ terhadap prestasi belajar dengan persamaan model $\hat{Y}=6,736+0,335 X_{1}+0,669 X_{2}$. Formula ini signifikan karena $F_{\text {hitung }}$ sebesar 58,582 dimana $F_{\text {hitung }}>3,30$ atau nilai Sig sebesar 0,000 dimana nilai Sig < 0,05, sehingga dapat disimpulkan terdapat hubungan yang signifikan antara motivasi belajar dan perhatian orang tua terhadap prestasi belajar matematika kelas VIII di SMPK Tunas Daud Mataram tahun pelajaran 2020/2021. Kontribusi hubungan antara motivasi belajar dan perhatian orang tua terhadap prestasi belajar matematika siswa kelas VIII di SMPK Tunas Daud Mataram Tahun Pelajaran 2020/2021 termasuk dalam tingkat hubungan yang sedang. Hal tersebut dapat ditunjukkan dengan nilai koefisien korelasi sebesar 0,511. Tingkat hubungan yang diberikan oleh motivasi belajar dan perhatian orang tua terhadap prestasi belajar matematika sebesar $77,7 \%$. A correlation measures the streght of the linier relation between $x$ and $y$. The stronger the correlation the better $x$ predict $y$ (Lyman ott, 2000). Dengan kata lain variabel motivasi belajar dan perhatian orang tua mampu menjelaskan variansi dari variabel prestasi belajar. Dan 22,3\% dipengaruhi oleh faktor lain. Adapun faktor lain yang dapat mempengaruhi adalah faktor inter dan faktor eksternal. Menurut Slameto (2010) faktor internal dan faktor eksternal yang dapat mempengaruhi belajar itu sendiri. Dalam penelitian ini dapat disimpulkan bahwa motivasi belajar dan perhatian orang tua mempengaruhi prestasi belajar matematika siswa kelas VIII di SMPK tunas Daud Mataram Tahun Pelajaran 2020/2021. Menurut Suryanto (dalam Prayitno, 2006) bahwa matematika masih sering disajikan sebagai barang siap pakai namun sangat jarang mengolahnya menjadi kegiatan. Diharapkan guru memberikan motivasi dan bimbingan agar menumbuhkan rasa percaya diri siswa di dalam diri. Selain itu diharapkan guru dapat menyampaikan materi pelajaran dengan cara atau metode yang menarik terutama pada pandemi Covid-19 seperti saat ini karena sebagian dari siswa merasa jenuh untuk belajar dari rumah serta 
berkurangnya interaksi secara langsung dengan teman maupun guru juga dapat menambah tingkat kejenuhan siswa yang belajar dari rumah. Selain itu, guru juga diharapkan lebih memperhatikan motivasi siswa selama pelajaran berlangsung karena tidak menutup kemungkinan siswa merasa malas untuk belajar secara daring.

\section{KESIMPULAN}

Berdasarkan hasil penelitian dan pembahasan yang telah diuraikan Bab V dapat ditarik kesimpulan, antara lain:

1. Terdapat pengaruh motivasi belajar terhadap prestasi belajar matematika siswa kelas VIII di SMPK Tunas Daud Mataram tahun pelajaran 2020/2021 dengan pengaruh sebesar 19,6\% termasuk dalam kategori rendah.

2. Terdapat pengaruh perhatian orang tua terhadap prestasi belajar matematika siswa kelas VIII di SMPK Tunas Daud Mataram tahun pelajaran 2020/2021 dengan pengaruh sebesar 19,2\% termasuk dalam kategori rendah.

3. Terdapat pengaruh secara bersama-sama motivasi belajar terhadap prestasi belajar matematika siswa kelas VIII di SMPK Tunas Daud Mataram tahun pelajaran 2020/2021 dengan pengaruh sebesar 77,7\%.

\section{REFERENSI}

Ahmadi, A. (2009). Psikologi sosial. Jakarta: Rineka Cipta.

Handayani, D. (2013). Pengaruh perhatian orang tua dan konsep diri siswa terhadap hasil belajar matematika siswa. Jurnal Pendidikan Dasar.

Sari, I. \& Harini, E. (2016). Hubungan antara perhatian orang tua dan gaya belajar dengan prestasi belajar matematika. Jurnal Pendidikan Matematika, (Vol. 4(3), pp. 391-396).

Gusnawati, Bey, A., \& Hasnawati. (2019). Pengaruh motivasi belajar terhadap hasil belajar matematika siswa kelas viii smp negeri 1 sawerigadi. Jurnal Penelitian Pendidikan Matematika, (Vol. 7(1), pp. 67).

Maonde, F. (2011). Aplikasi penelitian eksperimen dalam bidang pendidikan dan sosial. Kendari: Unhalu Press.

Maunah, B. (2014). Psikologi pendidikan. Yogyakarta: IAIN Tulungagung Press.

Prayitno, S. (2006). Model pembelajaran berdasar masalah untuk meningkatkan aktivitas dan hasil belajar pada perkuliahan teori peluang. Jurnal Kependidikan (No. 2).

R. Lyman Ott, Michael. T Lognecker. (2000). An introduce to statistical methods and data analysis. Texas A \& M University: USA.

Sadirman, AM. (2014). Interaksi dan motivasi belajar mengajar. Jakarta: PT Raja Grafindo.

Slameto. (2010). Belajar dan faktor-faktor yang mempengaruhi. Jakarta: Rineka Cipta.

Sobur, A. (2013). Psikologi umum dalam lintasan sejarah. Bandung: CV Pustaka Setia.

Sripatmi, Baidowi, \& Fitriani. (2019). Pengaruh motivasi dan kebiasaan belajar terhadap hasil belajar matematika siswa kelas xi sman 1 jonggat. Mandalika Mathematics and Educational Journal, (Vol. 1(2), pp. 104-112).

Sugiyono. (2016). Statistika untuk penelitian. Bandung: Alfabeta.

Suryabrata, S. (2011). Psikologi pendidikan. Jakarta: PT Raja Grafindo. 
Susanti, A. (2015). Pengaruh motivasi belajar siswa terhadap prestasi belajar matematika siswa. Jurnal Pendidikan Matematika STKIP PGRI Sidoarjo, (Vol. 3(1)). 